\title{
Diversity and ecology of poroid fungi (Agaricomycetes, Basidiomycota) of the Gunib Plateau, Dagestan
}

\author{
Sergey V. Volobuev ${ }^{1}$, Yuliya Yu. Ivanushenko² and Aziz B. Ismailov ${ }^{3}$ \\ ${ }^{1}$ Komarov Botanical Institute of the Russian Academy of Sciences, St. Petersburg, Russia \\ ${ }^{2}$ Dagestan State University, Makhachkala, Russia \\ ${ }^{3}$ Mountain Botanical Garden of the Dagestan Federal Scientific Centre of the Russian Academy of Sciences, Makhachkala, Russia
}

\section{Principal contact}

Sergey V. Volobuev, Candidate of Sciences (Biology), Senior Researcher, Laboratory of Systematics and Geography of Fungi, Komarov Botanical Institute, Russian Academy of Sciences; 2 Professora Popova St, Saint Petersburg, Russia 197376.

Tel. +78123725469

Email sergvolobuev@binran.ru ORCID https://orcid.org/0000-0003-1217-5548

\section{How to cite this article}

Volobuev S.V., Ivanushenko Yu.Yu., Ismailov A.B. Diversity and ecology of poroid fungi (Agaricomycetes, Basidiomycota) of the Gunib Plateau, Dagestan. South of Russia: ecology, development. 2021, vol. 16, no. 3, pp. 68-80. DOI: 10.18470/1992-1098-2021-3-68-80

Received 25 January 2021

Revised 11 March 2021

Accepted 26 April 2021

\begin{abstract}
Aim. Polypores are an integral part of forest ecosystems, but to date there is no sufficient information on diversity and ecology of this group of basidiomycetes in many mountain areas. The aim of this study is to reveal species composition and characterize substrate preferences of poroid fungi of the Gunib Plateau (the Republic of Dagestan, Northeast Caucasus, Russia).

Material and Methods. All fungal specimens were collected by the authors during field surveys in 2018-2020, which were carried out within pine, birch, hornbeam, alder, aspen, and mixed forests as well as juniper woodlands. The identification of fungi was performed predominantly by a light microscopy techniques, but also by an analysis of the ITS1-5.8S-ITS2 nrDNA to verify specimens from Postia caesia-species complex.

Results. A total of 73 species of poroid fungi from 43 genera and 7 orders of the class Agaricomycetes (Basidiomycota) have been identified in the territory of the Gunib Plateau within the Upper Gunib Nature Park. Among them, there are 29 new species for the Republic of Dagestan, of which 11 species are cited for the Caucasus for the first time. An annotated species list with detailed information on substrata, habitats, localities, and links to herbarium specimens (LE) is provided.

Conclusion. The revealed species richness of polypores has expanded the current knowledge on the mycobiota of the Gunib Plateau and its links with plant communities. The range of leading genera (Antrodia s. I., Ceriporia, Gloeophyllum, Phellinus s. I., Postia, Trametes s. I.) is characteristic of the boreal zone and determined by the predominance of Pinus kochiana forests in the surveyed area.
\end{abstract}

\section{Key Words}

Auriporia aurulenta, biodiversity, mountain habitats, Northeast Caucasus, polypores, wood-inhabiting fungi.

(C) 2021 The authors. South of Russia: ecology, development. This is an open access article under the terms of the Creative Commons Attribution License, which permits use, distribution and reproduction in any medium, provided the original work is properly cited. 


\title{
Разнообразие и экология пороидных грибов (Agaricomycetes, Basidiomycota) на территории плато Гуниб, Дагестан
}

\author{
Сергей В. Волобуев ${ }^{1}$, Юлия Ю. Иванушенко ${ }^{2}$, Азиз Б. Исмаилов ${ }^{3}$ \\ ${ }^{1}$ Ботанический институт им. В.Л. Комарова РАН, Санкт-Петербург, Россия \\ ${ }^{2}$ Дагестанский государственный университет, Махачкала, Россия \\ ${ }^{3}$ Горный ботанический сад ДФИЦ РАН, Махачкала, Россия
}

\section{Контактное лицо}

Сергей В. Волобуев, кандидат биологических наук, старший научный сотрудник лаборатории систематики и географии грибов, Ботанический институт им. В.Л. Комарова РАН; 197376

Россия, г. Санкт-Петербург, ул. Профессора

Попова, 2.

Тел. +78123725469

Email sergvolobuev@binran.ru ORCID https://orcid.org/0000-0003-1217-5548

\section{Формат цитирования}

Волобуев С.В., Иванушенко Ю.Ю., Исмаилов А.Б. Разнообразие и экология пороидных грибов (Agaricomycetes, Basidiomycota) на территории плато Гуниб, Дагестан // Юг России: экология, развитие. 2021. T.16, N 3. C. 68-80. DOI: 10.18470/1992-1098-2021-3-68-80

Получена 25 января 2021 г.

Прошла рецензирование 11 марта 2021 г. Принята 26 апреля 2021 г.

\begin{abstract}
Резюме
Цель. Трутовые грибы являются неотъемлемой частью лесных экосистем, но на сегодняшний день для многих горных территорий отсутствует информация о разнообразии и экологии этой группы базидиомицетов. Цель исследования - инвентаризация видового разнообразия и выявление субстратных предпочтений пороидных грибов на территории плато Гуниб (Дагестан, Северо-Восточный Кавказ).

Материал и методы. Образцы грибов были собраны авторами в ходе полевых исследований в 2018-2020 гг., которые проводились маршрутным методом в сосновых, березовых, грабовых, ольховых, осиновых и смешанных лесах, а также можжевеловых криволесьях. Идентификация грибов проводилась преимущественно методами световой микроскопии, а также на основе анализа ITS1-5.8S-ITS2 области ярДНК для проверки образцов из Postia caesia-комплекса.

Результаты. Всего на территории плато Гуниб в природном парке «Верхний Гуниб» идентифицировано 73 вида пороидных грибов из 43 родов и 7 порядков класса Agaricomycetes (Basidiomycota). Среди них 29 новых видов для Республики Дагестан, из которых 11 видов впервые указаны для Кавказа. Приведен аннотированный список видов с подробной информацией о субстратах, местообитаниях, местонахождениях и номерах гербарных образцов (LE).

Заключение. Выявленное видовое разнообразие пороидных грибов расширило современные знания о микобиоте плато Гуниб и ее связях с растительными сообществами. Спектр ведущих родов (Antrodia s. I., Ceriporia, Gloeophyllum, Phellinus s. I., Postia, Trametes s. I.) характерен для бореальной зоны и определяется преобладанием на обследованной территории сосновых лесов из Pinus kochiana.

Ключевые слова

Auriporia aurulenta, биоразнообразие, горные экосистемы, СевероВосточный Кавказ, трутовики, деревообитающие грибы.
\end{abstract}

(C) 2021 Авторы. Юг России: экология, развитие. Это статья открытого доступа в соответствии с условиями Сreative Commons Attribution License, которая разрешает использование, распространение и воспроизведение на любом носителе при условии правильного цитирования оригинальной работы. 


\section{INTRODUCTION}

Poroid fungi (Agaricomycetes, Basidiomycota) are an important non-taxonomic group of wood-inhabiting macrobasidiomycetes; their common morphological character is the poroid hymenophore. They play a significant role in biomass recycling in forest ecosystems [1], while forming ecological niches for other organisms. Many species of poroid fungi are causative agents of stem and root rot. Among species of poroid fungi are pathogens of living trees [2; 3], as well as mycorrhizal species, which form basidiomata on dead wood (e.g. among Sistotrema; $[4 ; 5])$. Several species are bioindicators of forest areas with a high conservation value, and a considerable number of species possess bioactive compounds with diverse biotechnological and pharmaceutical applications $[1 ; 6]$.

The article summarizes the data on the species diversity and ecological characteristics of poroid fungi obtained by the authors [7-10] and supplemented with information about new finds on the territory of the Gunib Plateau (Dagestan).

The Gunib Plateau occupies the northwestern part of Intramountain Dagestan, located in the northeast of the Greater Caucasus. Plateau height ranges from 1400 to 2351 $\mathrm{m}$ above sea level and the total area is about $14.7 \mathrm{~km}^{2}$ [11].

The plateau is particularly affected by a continental climate [11]. The annual rainfall is $680 \mathrm{~mm}$ with a June-July maximum. The average annual air temperature is $+6.7^{\circ} \mathrm{C}$. The coldest month is January with an average monthly temperature of $-5.2^{\circ} \mathrm{C}$ while the average temperature of the warmest month of August is $+16.5^{\circ} \mathrm{C}$. The period of temperatures above zero lasts on average for 270 days [10]. Relative humidity is $65 \%$.

The plateau is drained by the shallow river Gunibka, which receives mainly rain water [11].

In the flora of vascular plants of the Gunib plateau, there are 657 species. The general vegetation cover of the plateau consists of forest, meadow, mountain-steppe, and mountain-xerophytic communities with significant participation of petrophytes [12]. The forests of the Gunib Plateau are formed by Pinus kochiana, Betula litwinowii, $B$. pendula and $B$. raddeana, with an admixture of Salix caprea, Populus tremula, Carpinus betulus, Acer campestre, Sorbus torminalis, Tilia cordata and other trees [10].

The aim of the study was to reveal species composition and characterize substrate preferences of poroid fungi (Agaricomycetes, Basidiomycota) of the Gunib Plateau (the Republic of Dagestan, Northeast Caucasus).

\section{MATERIAL AND METHODS}

Specimens of wood-inhabiting fungi were collected in accordance with the standard techniques [13; 14] in September-October of 2018-2020 and May of 2019 on the territory of the Gunib Plateau during a route survey of forest ecosystems. The list of studied localities with geographical coordinates and altitudes is presented in Table 1.

Table 1. Geographical coordinates and altitudes of studied localities in the Gunib Plateau

Таблица 1. Географические координаты и высоты над уровнем моря обследованных локалитетов на плато Гуниб

\begin{tabular}{|c|c|c|c|}
\hline Locality number & Latitude & Longitude & Altitude \\
\hline$\# 1$ & $42.40075^{\circ} \mathrm{N}$ & $46.91889^{\circ} \mathrm{E}$ & $1720 \mathrm{~m}$ \\
\hline$\# 2$ & $42.403707^{\circ} \mathrm{N}$ & $46.911382^{\circ} \mathrm{E}$ & $1798 \mathrm{~m}$ \\
\hline$\# 3$ & $42.403593^{\circ} \mathrm{N}$ & $46.911264^{\circ} \mathrm{E}$ & $1810 \mathrm{~m}$ \\
\hline$\# 4$ & $42.409523^{\circ} \mathrm{N}$ & $46.908526^{\circ} \mathrm{E}$ & $1854 \mathrm{~m}$ \\
\hline$\# 5$ & $42.409617^{\circ} \mathrm{N}$ & $46.906868^{\circ} \mathrm{E}$ & $1881 \mathrm{~m}$ \\
\hline$\# 6$ & $42.409278^{\circ} \mathrm{N}$ & $46.904450^{\circ} \mathrm{E}$ & $1924 \mathrm{~m}$ \\
\hline \#7 & $42.409078^{\circ} \mathrm{N}$ & $46.901189^{\circ} \mathrm{E}$ & $1959 \mathrm{~m}$ \\
\hline$\# 8$ & $42.407591^{\circ} \mathrm{N}$ & $46.903117^{\circ} \mathrm{E}$ & $1920 \mathrm{~m}$ \\
\hline \#9 & $42.404557^{\circ} \mathrm{N}$ & $46.906402^{\circ} \mathrm{E}$ & $1874 \mathrm{~m}$ \\
\hline$\# 10$ & $42.403639^{\circ} \mathrm{N}$ & $46.921271^{\circ} \mathrm{E}$ & $1704 \mathrm{~m}$ \\
\hline \#11 & $42.404152^{\circ} \mathrm{N}$ & $46.921312^{\circ} \mathrm{E}$ & $1692 \mathrm{~m}$ \\
\hline$\# 12$ & $42.404383^{\circ} \mathrm{N}$ & $46.914534^{\circ} \mathrm{E}$ & $1716 \mathrm{~m}$ \\
\hline$\# 13$ & $42.403555^{\circ} \mathrm{N}$ & $46.912575^{\circ} \mathrm{E}$ & $1815 \mathrm{~m}$ \\
\hline$\# 14$ & $42.410924^{\circ} \mathrm{N}$ & $46.908791^{\circ} \mathrm{E}$ & $1808 \mathrm{~m}$ \\
\hline$\# 15$ & $42.409787^{\circ} \mathrm{N}$ & $46.907016^{\circ} \mathrm{E}$ & $1876 \mathrm{~m}$ \\
\hline$\# 16$ & $42.410041^{\circ} \mathrm{N}$ & $46.905304^{\circ} \mathrm{E}$ & $1925 \mathrm{~m}$ \\
\hline$\# 17$ & $42.412403^{\circ} \mathrm{N}$ & $46.910023^{\circ} \mathrm{E}$ & $1716 \mathrm{~m}$ \\
\hline$\# 18$ & $42.411631^{\circ} \mathrm{N}$ & $46.914462^{\circ} \mathrm{E}$ & $1701 \mathrm{~m}$ \\
\hline \#19 & $42.405913^{\circ} \mathrm{N}$ & $46.920473^{\circ} \mathrm{E}$ & $1603 \mathrm{~m}$ \\
\hline$\# 20$ & $42.396452^{\circ} \mathrm{N}$ & $46.925452^{\circ} \mathrm{E}$ & $1630 \mathrm{~m}$ \\
\hline$\# 21$ & $42.394918^{\circ} \mathrm{N}$ & $46.925022^{\circ} \mathrm{E}$ & $1685 \mathrm{~m}$ \\
\hline$\# 22$ & $42.394227^{\circ} \mathrm{N}$ & $46.924735^{\circ} \mathrm{E}$ & $1724 \mathrm{~m}$ \\
\hline \#23 & $42.395467^{\circ} \mathrm{N}$ & $46.922518^{\circ} \mathrm{E}$ & $1717 \mathrm{~m}$ \\
\hline \#24 & $42.397379^{\circ} \mathrm{N}$ & $46.922712^{\circ} \mathrm{E}$ & $1679 \mathrm{~m}$ \\
\hline$\# 25$ & $42.396977^{\circ} \mathrm{N}$ & $46.922749^{\circ} \mathrm{E}$ & $1663 \mathrm{~m}$ \\
\hline$\# 26$ & $42.395996^{\circ} \mathrm{N}$ & $46.921136^{\circ} \mathrm{E}$ & $1718 \mathrm{~m}$ \\
\hline$\# 27$ & $42.395962^{\circ} \mathrm{N}$ & $46.919903^{\circ} \mathrm{E}$ & $1759 \mathrm{~m}$ \\
\hline$\# 28$ & $42.393162^{\circ} \mathrm{N}$ & $46.929143^{\circ} \mathrm{E}$ & $1701 \mathrm{~m}$ \\
\hline$\# 29$ & $42.392732^{\circ} \mathrm{N}$ & $46.931507^{\circ} \mathrm{E}$ & $1685 \mathrm{~m}$ \\
\hline$\# 30$ & $42.392758^{\circ} \mathrm{N}$ & $46.935123^{\circ} \mathrm{E}$ & $1573 \mathrm{~m}$ \\
\hline \#31 & $42.391788^{\circ} \mathrm{N}$ & $46.936204^{\circ} \mathrm{E}$ & $1617 \mathrm{~m}$ \\
\hline \#32 & $42.390799^{\circ} \mathrm{N}$ & $46.936711^{\circ} \mathrm{E}$ & $1632 \mathrm{~m}$ \\
\hline \#33 & $42.39073^{\circ} \mathrm{N}$ & $46.938541^{\circ} \mathrm{E}$ & $1567 \mathrm{~m}$ \\
\hline$\# 34$ & $42.404084^{\circ} \mathrm{N}$ & $46.911848^{\circ} \mathrm{E}$ & $1812 \mathrm{~m}$ \\
\hline \#35 & $42.40274^{\circ} \mathrm{N}$ & $46.921363^{\circ} \mathrm{E}$ & $1654 \mathrm{~m}$ \\
\hline$\# 36$ & $42.405848^{\circ} \mathrm{N}$ & $46.904889^{\circ} \mathrm{E}$ & $1895 \mathrm{~m}$ \\
\hline
\end{tabular}


Identification of the collected material was performed using a LOMO Mikmed-6 microscope (magnifications 600x and $1500 \times$ with oil immersion lens), a standard set of chemicals ( $5 \% \mathrm{KOH}$, Melzer reagent, $0.1 \%$ cotton blue), and modern monographs on polypores [15; 16]. The specimens studied were deposited into the Mycological Herbarium of the Komarov Botanical Institute of RAS (LE), Saint Petersburg.

The analysis of the ITS1-5.8S-ITS2 nrDNA was applied to verify specimens from Postia caesia-species complex [17]. DNA was amplified directly from dried specimens with a Phire Plant Direct PCR Master Mix Kit (Thermo Fisher Scientific, Lithuania). Amplification of the ITS region was done using a primer pair ITS1F/ITS4B [18;
19]. PCR products were purified with a Fermentas Genomic DNA Purification Kit (Thermo Fisher Scientific, Lithuania) and sequenced on an ABI Prism 3500 Genetic Analyzer (Applied Biosystems). Raw data were edited and assembled in MEGA 6 [20]. A BLAST analysis was carried out at the NCBI website [21].

Newly generated sequences (OK356489, OK356490) were deposited in GenBank. Additionally, 29 ITS sequences were retrieved from GenBank [22] (Table 2). Sequences were aligned with a MAFFT version 7 web tool [23; 24] using the E-INS-1 option. Maximum Likelihood (ML) analysis was performed in a IQ-TREE Web Server [25] with 1000 ultrafast bootstrap replicates.

Table 2. Sequences used in this study

Таблица 2. Нуклеотидные последовательности, использованные в данном исследовании

\begin{tabular}{|c|c|c|c|}
\hline Species & $\begin{array}{c}\text { GenBank } \\
\text { accessions }\end{array}$ & Specimen voucher & Origin (country) \\
\hline Antrodia pulvinascens & JQ700286 & Pennanen $1532(\mathrm{H})$ & Finland \\
\hline Postia alni & MG137026 & Vampola 12.10.1995 (H 7019137), isotype & Slovakia \\
\hline Postia alni & MG137028 & Larsson 18.09.2014 (O F-248173) & Norway \\
\hline Postia alni & OK356489 & Volobuev 29.09.2019 (LE F-334625) & Russia \\
\hline Postia auricoma & MG137040 & Niemelä 8310 (H 6014002), holotype & Finland \\
\hline Postia auricoma & MG137042 & Spirin $4586(\mathrm{H})$ & Russia \\
\hline Postia bubalina & MW182172 & Cui 16976 & China \\
\hline Postia bubalina & MW182173 & Cui 16985 & China \\
\hline Postia caesia & MG137045 & Schuster 51 (LY BR-6776), neotype & Germany \\
\hline Postia caesia & MG137047 & Miettinen $14133(\mathrm{H})$ & United Kingdom \\
\hline Postia caesiosimulans & MG137054 & Miettinen 16976,1 (H 7008645), epitype & USA \\
\hline Postia caesiosimulans & MG137056 & Miettinen $17075(\mathrm{H})$ & USA \\
\hline Postia cyanescens & MG137067 & Miettinen 13602 (H 6014001), holotype & Finland \\
\hline Postia cyanescens & MG137071 & Miettinen 15919,2 (H) & Spain \\
\hline Postia glauca & MG137078 & Spirin 5317 (H 7008648), holotype & Russia \\
\hline Postia glauca & MG137079 & Miettinen $10567(\mathrm{H})$ & China \\
\hline Postia luteocaesia & MG137091 & Rivoire 2605 (LY) & France \\
\hline Postia magna & КС595944 & Miettinen 10634 (H 7008643), holotype & China \\
\hline Postia magna & MW182180 & Cui 16983 & China \\
\hline Postia mediterraneocaesia & KX900886 & LY BR 4274 & France \\
\hline Postia populi & MG137092 & Miettinen 17043 (H 7008644), holotype & USA \\
\hline Postia populi & MG137097 & Niemelä 8379 (H 6007874) & Finland \\
\hline Postia simulans & MG137103 & Niemelä 8846 (H 6034704), epitype & Finland \\
\hline Postia simulans & MG137110 & Miettinen $20422(\mathrm{H})$ & Finland \\
\hline Postia simulans & MG137112 & Spirin $4386(\mathrm{H})$ & Russia \\
\hline Postia subviridis & MG137120 & Spirin 8774a $(\mathrm{H})$ & USA \\
\hline Postia tenuis & KX900885 & Cui 10788 & China \\
\hline Postia tenuis & KX900884 & Dai 12974 & China \\
\hline Postia yanae & MG137121 & Kotiranta 27454 (H 7034942), holotype & Russia \\
\hline Postia yanae & MG137122 & Kotiranta $27606(\mathrm{H})$ & Russia \\
\hline Postia yanae & OK356490 & Volobuev 06.10.2018 (LE F-334630) & Russia \\
\hline
\end{tabular}

\section{RESULTS AND DISCUSSION}

As a result of the 3-year long field survey in forests of the Gunib Plateau, 73 species of poroid fungi from 43 genera and 7 orders (Agaricomycetes, Basidiomycota) have been registered. Among them, there are 29 new species for the Republic of Dagestan, of which 11 species are cited for the Caucasus for the first time. Species new to the Caucasus are Antrodia minuta, Antrodiella ichnusana, Cartilosoma ramentaceum, Ceriporia torpida, Kneiffiella abdita, Postia alni, P. lateritia, P. leucomallella, P. yanae, Sistotrema alboluteum, S. muscicola.

New locations of Auriporia aurulenta were noted, a rare species protected in the Republic of Dagestan [26], as well as a number of Eurasian rare taxa (Ceriporia torpida, Kneiffiella abdita, Sistotrema alboluteum).
The Gunib record of Postia yanae is extremely remarkable, since the species has previously been known only from Eastern Siberia [17]. The identification based on microscopic features is confirmed by $99 \%$ similarity of the ITS nrDNA sequences and a phylogenetic analysis (Fig. 1). Our find of the species has common ecological characters with the Siberian collections being a coniferous-dwelling fungus in mountain forest ecosystems.

Based on results of the ML analysis of ITS nrDNA, the following combination in the genus Postia is introduced:

Postia bubalina (B.K. Cui \& Shun Liu) Ivanushenko \& Volobuev comb. nova (MB841410).

Basionym: Cyanosporus bubalinus B.K. Cui \& Shun Liu, Frontiers in Microbiology 12 (no. 631166): 5 (2021) 


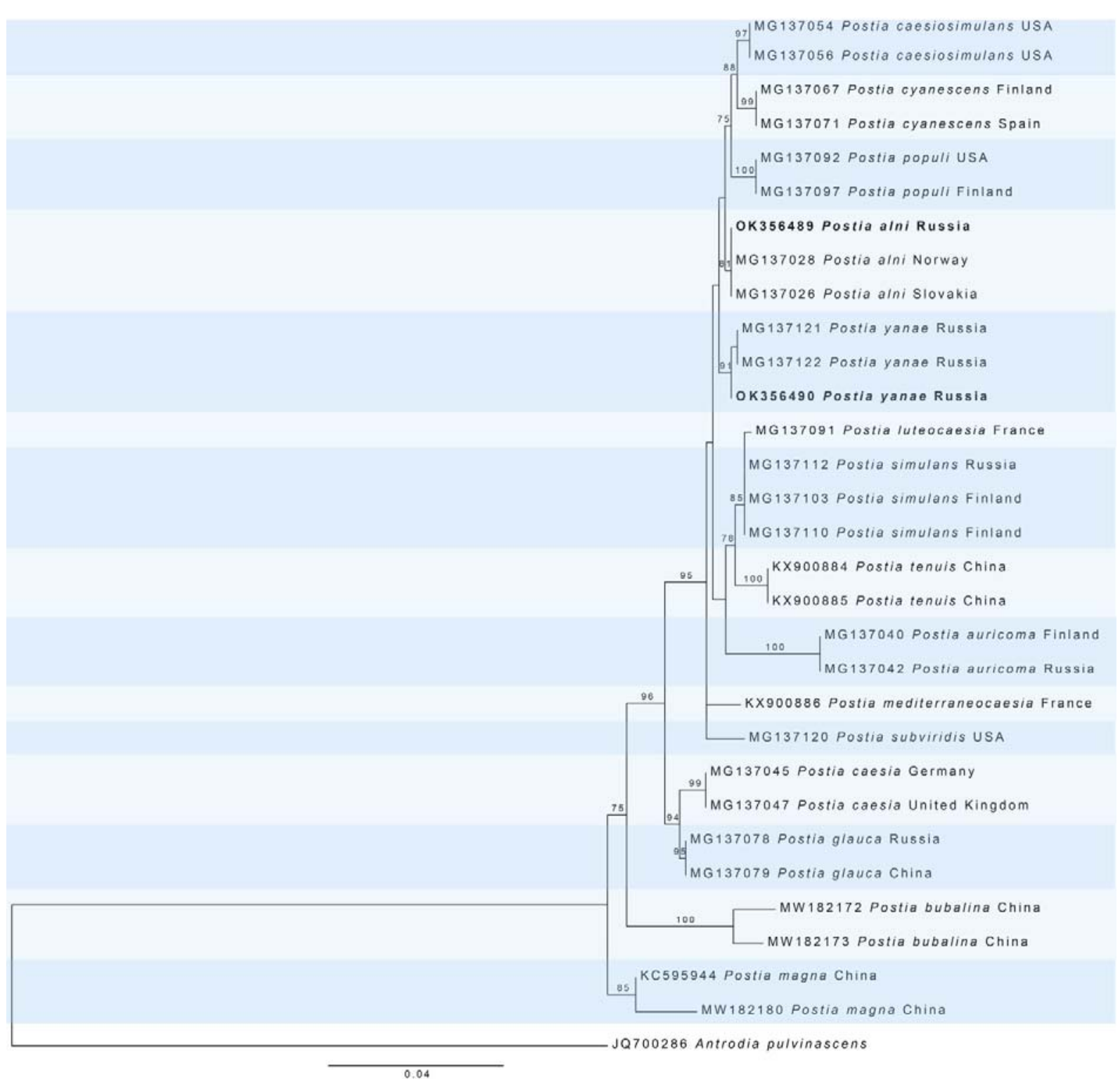

Figure 1. The Maximum Likelihood tree illustrating the phylogeny of Postia species, based on ITS sequence dataset Ultrafast bootstrap values (\%) not less than 75 are shown above the branches. Sequence accession numbers (GenBank) are indicated before species names. The sequences obtained in this study are written in bold

Рисунок 1. Дерево, построенное методом максимального правдоподобия и иллюстрирующее филогению видов Postia, на основе ITS-последовательностей. Значения ultrafast bootstrap (не менее 75\%) показаны над ветвями. Номера последовательностей (в базе данных GenBank) отобранных таксонов указаны перед видовыми названиями. Жирным шрифтом выделены названия нуклеотидных последовательностей, полученных в данном исследовании

The highest species richness was registered within the genera Antrodia s. I. (with Amyloporia and Cartilosoma) (5 species), Ceriporia (5 species), Gloeophyllum (4 species), Phellinus s. I. (with Fomitiporia, Fuscoporia, Phellinopsis) (8 species), Postia (7 species), Trametes s. I. (with Lenzites and Pycnoporus) (8 species). This spectrum of leading genera is characteristic of the boreal zone and is determined by the predominance of pine forests with Pinus kochiana in the surveyed area.

Most of fungal species were found on wood of Betula spp., including Betula litwinowii, B. pendula and $B$. raddeana (34 species), and Pinus kochiana (26 species). Irpex lacteus recorded on six tree species had the widest host range (Alnus, Betula, Carpinus, Juniperus, Pinus, Populus). Eleven species of xylotrophic fungi were associated with living trees, including three species exhibiting facultative phytopathogenic activity (Fomes fomentarius, Fomitopsis betulina, Phellinopsis conchata).
The list of species is provided below with data on localities, occupied substrata, types of habitat and herbarium numbers of specimens examined. The nomenclature of fungal taxa follows the Index Fungorum (2021) [27]. The species new to the Republic of Dagestan are marked with "!" and new to the Caucasus - with "!!".

\section{Annotated list of species} AGARICALES

! Porotheleum fimbriatum (Pers.) Fr. - \#5, \#1: on fallen trunks of Betula spp. and on fallen branches of Pinus kochiana in herb-rich birch forests (LE F-334622).

\section{CANTHARELLALES}

!! Sistotrema alboluteum (Bourdot \& Galzin) Bondartsev \& Singer - \#16: on fallen trunk of Pinus kochiana in herb-rich pine-dominated forest (LE F-334636). The species has a scattered distribution in Europe [16], growing on very 
rotten wood and plant remnants mainly in moist broadleaf and mixed deciduous-coniferous forests. The Gunib find of S. alboluteum seems to be corresponding to a suitable humidity and low anthropogenic pressure in the forests of the Plateau.

!! Sistotrema muscicola (Pers.) S. Lundell - \#5: on fallen trunk of Betula sp. in herb-rich birch forest (LE F334637).

\section{GLOEOPHYLLALES}

! Gloeophyllum abietinum (Bull.) P. Karst. - \#8: on fallen trunk of Pinus kochiana in herb-green-moss pinedominated forest with birch (LE F-334599).

Gloeophyllum protractum (Fr.) Imazeki - \#8: on fallen trunk of Pinus kochiana in herb-green-moss pinedominated forest with birch (LE F-334598).

Gloeophyllum sepiarium (Wulfen) P. Karst. - \#32: on fallen branches of Pinus kochiana in green-moss pinedominated forest (LE F-334601).

Gloeophyllum trabeum (Pers.) Murrill - \#35: on timber wood of Pinus kochiana (LE F-334600).

\section{HYMENOCHAETALES}

! Fomitiporia punctata (P. Karst.) Murrill - \#11, \#23: on living trees of Salix caprea in herb-rich pine-dominated forest with birch and herb-rich birch forest with pine (LE F334615).

Fuscoporia contigua (Pers.) G. Cunn. - \#28: on fallen branches of Carpinus betulus in herb-rich aspen forest with hornbeam (LE F-334611).

Fuscoporia ferruginosa (Schrad.) Murrill - \#2, \#5: on fallen trunk and branches of Betula sp. in herb-rich birch forests (LE F-334616).
Inonotus obliquus (Fr.) Pilát - \#2: on living tree of Betula sp. in herb-rich pine-dominated forest with birch (LE F-334604).

!! Kneiffiella abdita Riebesehl \& Langer - \#16, \#19: on fallen trunks of Pinus kochiana in herb-rich pinedominated forest and herb-fern birch forest with alder (LE F-334605). This species is known from a few countries in Europe, otherwise known in East Asia and North America [15], but extremely rare everywhere. In Russia, K. abdita has only been registered in seven regions, namely in Komi Republic and Leningrad Region, being included in the regional Red Data Books [28; 29], as well as in Oryol Region [30; 31], Rostov Region [32], Tver Region [33], Sverdlovsk Region [34], and Novosibirsk Region [35].

Oxyporus corticola (Fr.) Ryvarden - \#28: on fallen trunk of Populus tremula in herb-rich aspen forest with hornbeam (LE F-334609).

Phellinopsis conchata (Pers.) Y.C. Dai - \#7, \#1: on fallen trunk of Betula sp. and on living tree of Salix caprea in herb-green-moss pine-dominated forest and herb-rich birch forest (LE F-334610).

! Phellinus laevigatus (P. Karst.) Bourdot \& Galzin \#9: on dead standing tree of Betula sp. in herb-green-moss birch forest with pine (LE F-334612).

! Phellinus lundellii Niemelä - \#8: on fallen trunk of Betula sp. in herb-green-moss pine-dominated forest with birch (LE F-334613).

Phellinus nigricans (Fr.) P. Karst. - \#2: on living tree of Betula sp. in herb-rich birch forest (LE F-334614).

Phellinus tremulae (Bondartsev) Bondartsev \& P.N. Borisov - \#24: on living tree of Populus tremula in herb-rich aspen forest (Fig. 2).

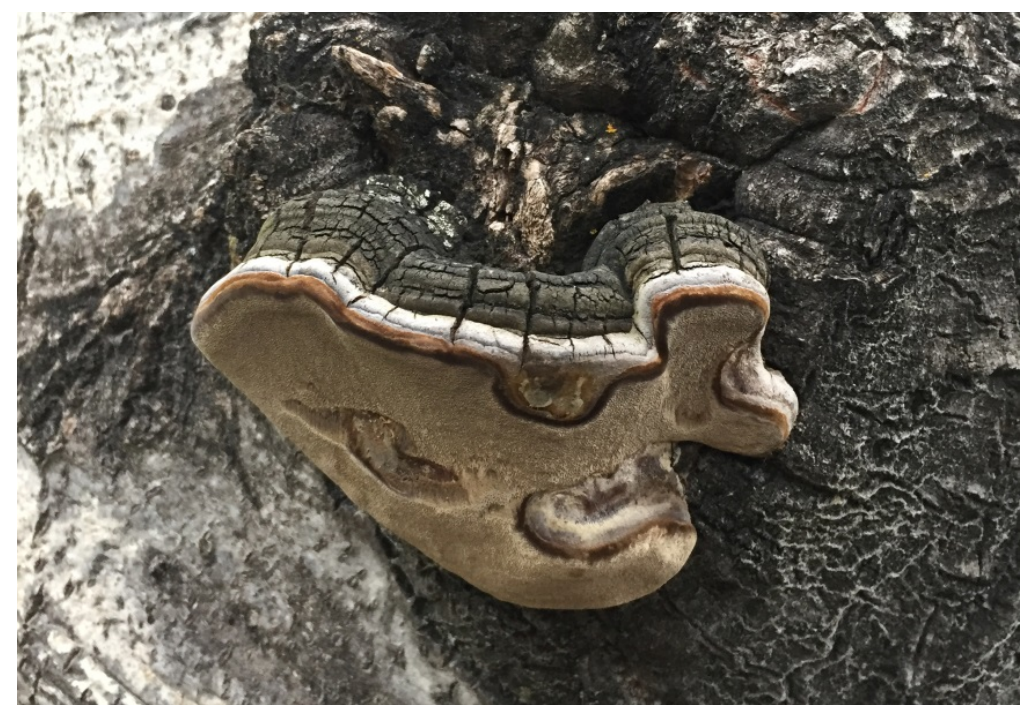

Figure 2. Basidiocarp of Phellinus tremulae (not documented by voucher). Photo S.V. Volobuev

Рисунок 2. Базидиома Phellinus tremulae (образец не собран). Фото С.В. Волобуева

! Phylloporia ribis (Schumach.) Ryvarden - \#33: on living stem of Euonymus verrucosus in herb-fern aspen forest with pine (LE F-334617).

! Sidera lenis (P. Karst.) Miettinen - \#6, \#16: on fallen trunks of Pinus kochiana in herb-rich pine-dominated forest and herb-green-moss pine-dominated forest (LE F334634).

Sidera vulgaris (Fr.) Miettinen - \#4: on fallen trunk of Pinus kochiana in herb-rich pine-dominated forest (LE F334635).
Trichaptum fuscoviolaceum (Ehrenb.) Ryvarden \#9: on fallen branches of Pinus kochiana in herb-rich birch forest with pine (LE F-334646).

Xylodon flaviporus (Berk. \& M.A. Curtis ex Cooke) Riebesehl \& Langer - \#3, \#4, \#5: on fallen trunk and branches of Betula spp. in herb-rich birch forests (LE F334632).

Xylodon raduloides Riebesehl \& Langer - \#3, \#28: on fallen trunk of Betula sp. and on dry attached branches of Carpinus betulus in herb-rich birch forest and herb-rich aspen forest with hornbeam (LE F-334633). 


\section{POLYPORALES}

Amyloporia sinuosa (Fr.) Rajchenb., Gorjón \& Pildain - \#5, $\# 6, \# 7, \# 8, \# 15, \# 95, \# 23, \# 27, \# 30$ : on fallen trunks of Pinus kochiana and Betula spp. in herb-green-moss pinedominated forests, herb-green-moss pine-dominated forests with birch, herb-rich pine-dominated forest, herbrich pine-dominated forest with birch and hornbeam and herb-rich birch forest (LE F-334581, LE F-334582, LE F334583).

! Amyloporia xantha (Fr.) Bondartsev \& Singer \#14: on fallen branches of Pinus kochiana in herb-greenmoss pine-dominated forest with birch (LE F-334584).

!! Antrodia minuta Spirin - \#28: on fallen trunk and branches of Populus tremula in herb-rich aspen forest with hornbeam (LE F-334577, LE F-334578).
! Antrodia serialis (Fr.) Donk - \#34: on fallen branches of Pinus kochiana in herb-rich pine-dominated forest with birch (LE F-334580).

!! Antrodiella ichnusana Bernicchia, Renvall \& Arras - \#18: on dry attached branches of Alnus incana in herbfern birch forest with alder (LE F-334585).

! Aurantiporus fissilis (Berk. \& M.A.Curtis) H.Jahn ex Ryvarden - \#153: on living tree of Betula sp. in herb-rich birch forest (LE F-334586).

Auriporia aurulenta A. David, Tortič \& Jelić - \#8, $\# 23$, \#26: on fallen trunks of Pinus kochiana in herb-greenmoss pine-dominated forest (LE F-334587, LE F-334589) (Fig. 3).

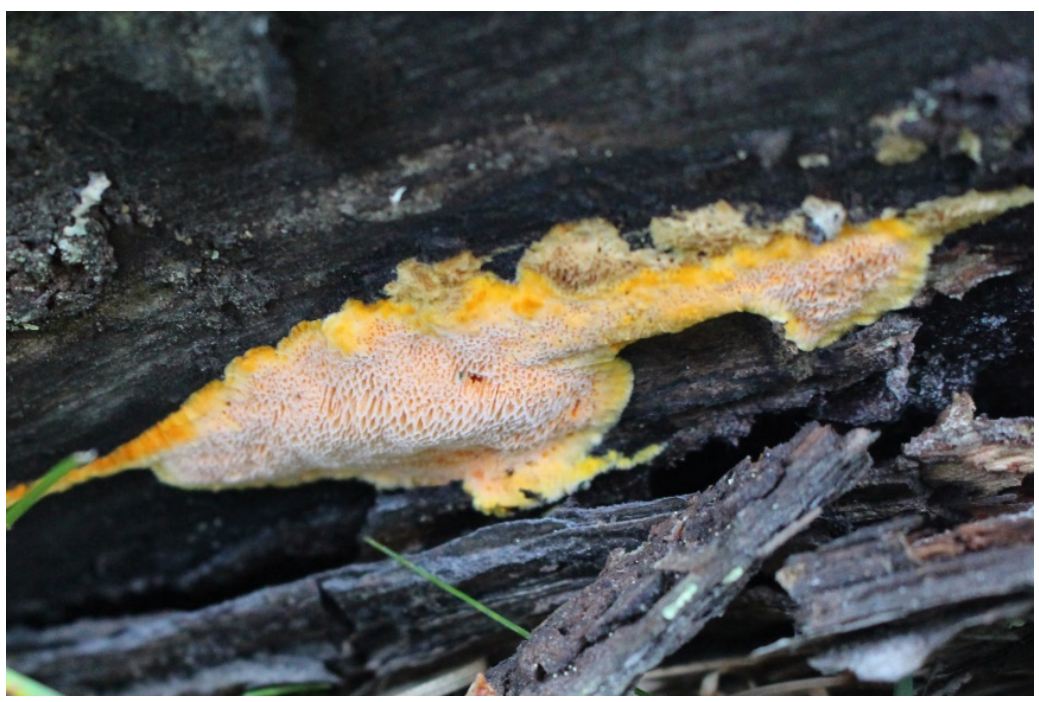

Figure 3. Basidiocarp of Auriporia aurulenta (LE F-334589). Photo Yu.Yu. Ivanushenko Рисунок 3. Базидиома Auriporia aurulenta (LE F-334589). Фото Ю.Ю. Иванушенко

Bjerkandera adusta (Willd.) P. Karst. - \#12, \#31: on stump of Betula sp. and on dead standing tree of Populus tremula in herb-fern birch forest and herb-green-moss aspen forest (LE F-334588).

!! Cartilosoma ramentaceum (Berk. \& Broome) Teixeira - \#9: on fallen trunk of Pinus kochiana in herb-rich birch forest with pine (LE F-334579).

! Ceriporia aurantiocarnescens (Henn.) M. Pieri \& B. Rivoire - \#12: on stump of Betula sp. in herb-fern birch forest (LE F-334590). The species was previously known for the Caucasus only from Georgia [36].

Ceriporia bresadolae (Bourdot \& Galzin) Donk - \#6, \#25, \#32: on fallen trunks and branches of Pinus kochiana in green-moss pine-dominated forest, herb-green-moss pine-dominated forest, herb-green-moss pine-dominated forest with birch (LE F-334590).

! Ceriporia purpurea (Fr.) Donk - \#11: on dry attached branch of Salix caprea in herb-rich pinedominated forest with birch (LE F-334591).

!! Ceriporia torpida Spirin \& Miettinen - \#17: on fallen branches of Alnus incana in floodplain alder forest (LE F-334592). The first Russian finds of this species were registered in the European part of Russia as a result of xylotrophic pathogenic fungi inventory studies in orchards [37]. Our record of $C$. torpida on the Gunib Plateau is the first collection in the Caucasus and has been proved by both a microscopic study and an analysis of the ITS nrDNA sequence (unpublished data).

Ceriporia viridans (Berk. \& Broome) Donk - \#13, \#23: on fallen trunks of Betula spp. in herb-rich birch forest and herb-rich birch forests with pine (LE F-334593).

Cerrena unicolor (Bull.) Murrill - \#5: on fallen trunk of Betula sp. in herb-rich birch forest (LE F-334594).

Daedaleopsis confragosa (Bolton) J. Schröt. - \#1: on living tree of Salix caprea in herb-rich birch forest (LE F334596).

Daedaleopsis tricolor (Bull.) Bondartsev \& Singer \#2: on fallen trunk of Salix caprea in herb-rich birch forest (LE F-334595).

! Diplomitoporus flavescens (Bres.) Domański - \#36: on dry standing tree of Pinus kochiana in herb-green-moss pine-dominated forest (LE F-334648).

Fomes fomentarius (L.) Fr. - \#12, \#14, \#17, \#19: on dry standing trees and fallen trunks of Alnus incana and Betula sp., on living tree of Salix caprea in herb-rich birch forests, herb-rich pine-dominated forest with birch and floodplain alder forest with birch and hornbeam.

Fomitopsis betulina (Bull.) B.K. Cui, M.L. Han \& Y.C. Dai - \#17: on dry standing trees, fallen trunks and branches of Betula spp., on living tree of Betula raddeana in herbrich pine-dominated forest, herb-rich pine-dominated forest with birch, herb-fern birch forest, floodplain alder forest. 


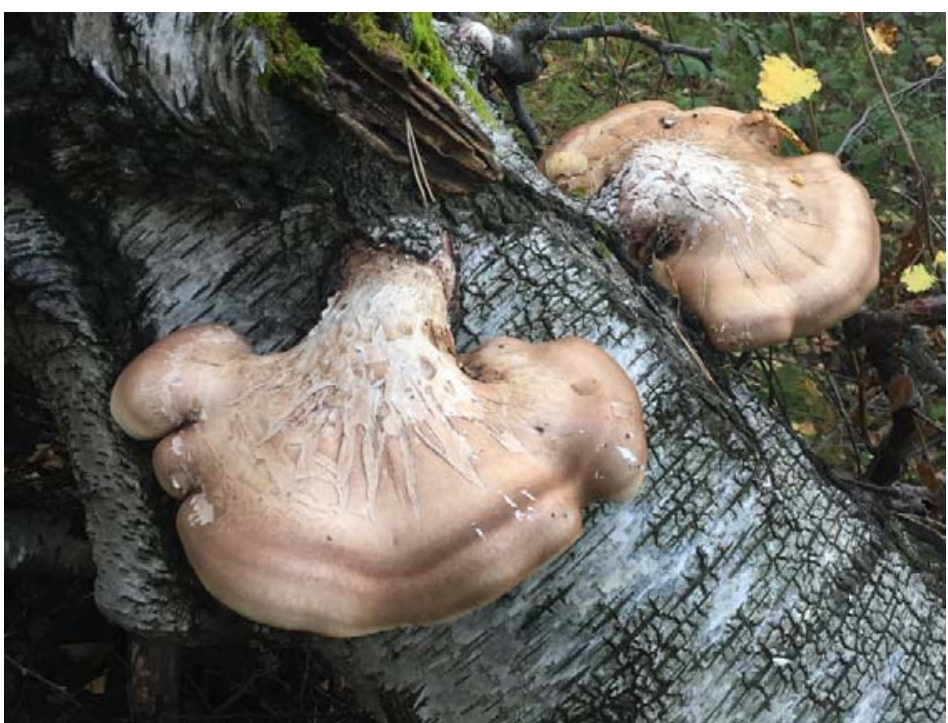

Figure 4. Basidiocarps of Fomitopsis betulina (not documented by voucher). Photo S.V. Volobuev Рисунок 4. Базидиомы Fomitopsis betulina (образец не собран). Фото С.В. Волобуева

Fomitopsis pinicola (Sw.) P. Karst. - \#18: on fallen trunks of Alnus incana, Betula sp., Carpinus betulus in herb-rich pinedominated forest with birch and floodplain alder forest with birch and hornbeam.

Funalia trogii (Berk.) Bondartsev \& Singer - \#24, \#28: on fallen trunk and branches of Populus tremula in herb-rich aspen forest and herb-rich aspen forest with hornbeam (LE F-334640).

Ganoderma applanatum (Pers.) Pat. - \#2, \#34: on stump of Betula sp. and on dead standing tree of Salix caprea in herb-rich birch forest and herb-rich birch forest with pine (LE F-334597).

Irpex lacteus (Fr.) Fr. - \#2, \#6, \#8, \#9, \#17, \#20, \#22, \#24: on stump of Betula sp., on fallen trunks and branches of Alnus incana, Betula spp., Carpinus betulus, Pinus kochiana, Populus tremula, on dry attached branches of Juniperus oblonga in floodplain alder forest, herb-rich aspen forest, herb-rich birch forest with hornbeam, herbrich birch forest with pine, herb-green-moss pinedominated forest, herb-rich pine-dominated forest with birch (LE 314757).
Lentinus arcularius (Batsch) Zmitr. - \#1, \#9, \#11: on fallen trunk and branches of Betula sp. and on fallen trunk of Salix caprea in herb-rich birch forest, herb-rich birch forest with pine and herb-rich pine-dominated forest with birch (LE F-334618).

Lentinus brumalis (Pers.) Zmitr. - \#5, \#8, \#9: on fallen trunk and branches of Betula sp. in herb-rich birch forest, herb-green-moss pine-dominated forest with birch and herb-rich birch forest with pine (LE F-334620).

Lenzites betulina (L.) Fr. - \#9: on fallen trunk of Salix caprea in herb-green-moss birch forest with pine (LE F-334606).

Lenzites warnieri Durieu \& Mont. - \#9: on fallen trunk of Betula sp. in herb-rich birch forest with pine (LE F334607).

Meruliopsis taxicola (Pers.) Bondartsev - \#7, \#10: on fallen trunk, fallen and dry attached branches of Pinus kochiana in herb-green-moss pine-dominated forests and herb-rich pine-dominated forest with birch (LE F-334602).

Picipes badius (Pers.) Zmitr. \& Kovalenko - \#10: at the base of living tree of Betula sp. in herb-rich pinedominated forest with birch (LE F-334619) (Fig. 5).

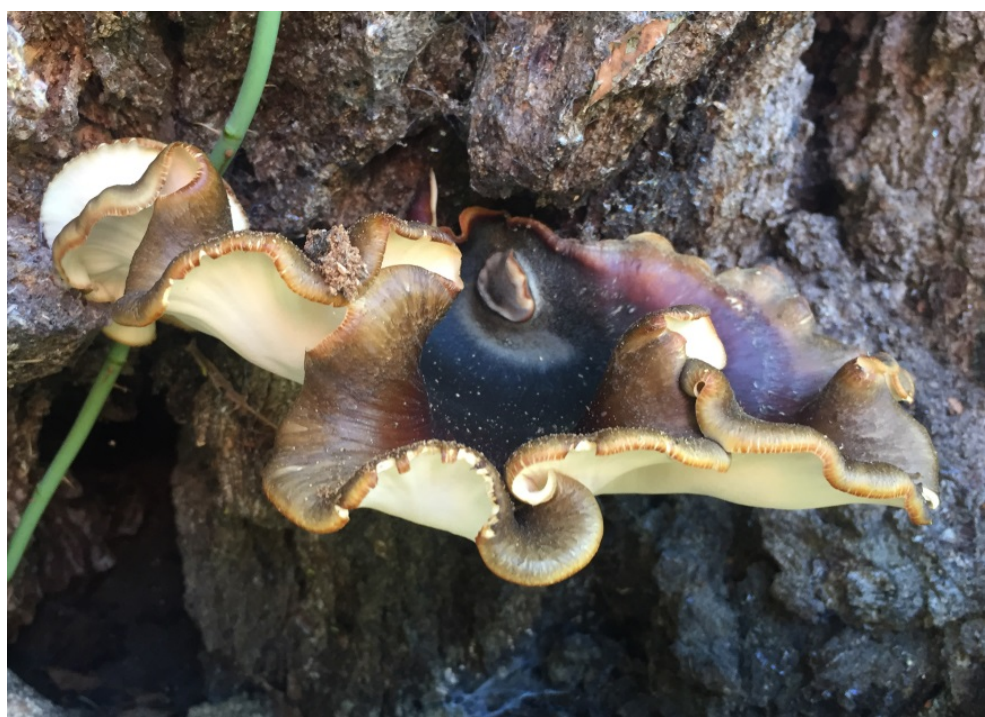

Figure 5. Basidiocarps of Picipes badius (LE F-334619). Photo S.V. Volobuev

Рисунок 5. Базидиомы Picipes badius (LE F-334619). Фото С.В. Волобуева 
! Polyporus leptocephalus (Jacq.) Fr. - \#9: on fallen trunk of Betula sp. in herb-green-moss birch forest with pine (LE F334621).

!! Postia alni Niemelä \& Vampola - \#21, \#28: on fallen branches of Populus tremula and Tilia cordata in herb-rich aspen forest with hornbeam and herb-rich birch forest with hornbeam (LE F-334624, LE F-334625).

Postia caesia (Schrad.) P. Karst. - \#6: on fallen trunk of Pinus kochiana in herb-green-moss pine-dominated forest (LE F-334608).

! Postia hibernica (Berk. \& Broome) Jülich - \#9: on fallen trunk of Pinus kochiana in herb-green-moss birch forest with pine (LE F-334626). The species was previously known for the Caucasus only from Iran [38; 39].

Postia lactea (Fr.) P. Karst. - \#1: on fallen branches of Juniperus oblonga in herb-rich birch forest (LE 314760).

!! Postia lateritia Renvall - \#6, \#26: on fallen trunks of Pinus kochiana in herb-green-moss pine-dominated forests (LE F-334627).

!! Postia leucomallella (Murrill) Jülich - \#8, \#31: on fallen trunks and branches of Pinus kochiana in herb-green- moss pine-dominated forest and herb-green-moss pinedominated forest with birch (LE F-334628).

!! Postia yanae Miettinen \& Kotir. - \#8: on fallen trunk of Pinus kochiana in herb-green-moss pinedominated forest with birch (LE F-334630). Based on a megablast search of NCBI GenBank nucleotide database [21; 22], the ITS sequence had highest similarity to Postia yanae (voucher Heikki Kotiranta 27879 (H 7036282), GenBank MG137125; Identities = 730/732 (99\%), no gaps), P. yanae (voucher Heikki Kotiranta $27606(\mathrm{H})$, GenBank MG137122; Identities = 729/731 (99\%), no gaps) and $P$. yanae (voucher Heikki Kotiranta $27677(\mathrm{H})$, GenBank MG137123; Identities = 728/730 (99\%), no gaps).

! Pycnoporus cinnabarinus (Jacq.) P. Karst. - \#5, \#9, \#26: on fallen trunks and branches of Betula spp. in herbrich birch forest, herb-rich birch forest with pine and herbgreen-moss pine-dominated forest with birch (LE F-334631) (Fig. 6).

Skeletocutis amorpha (Fr.) Kotl. \& Pouzar - \#8, \#23, $\# 25$ : on fallen trunks of Pinus kochiana in herb-green-moss pine-dominated forest and herb-green-moss pinedominated forest with birch (LE F-334638) (Fig. 7).

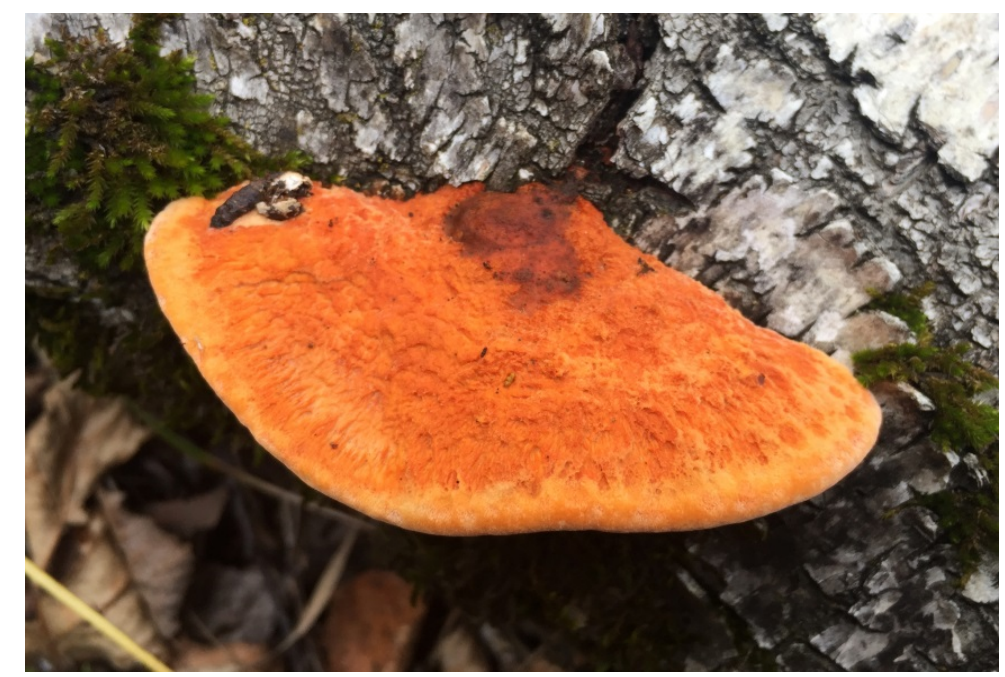

Figure 6. Basidiocarp of Pycnoporus cinnabarinus (LE F-334631). Photo Yu.Yu. Ivanushenko Рисунок 6. Базидиома Pусnoporus cinnabarinus (LE F-334631). Фото Ю.Ю. Иванушенко

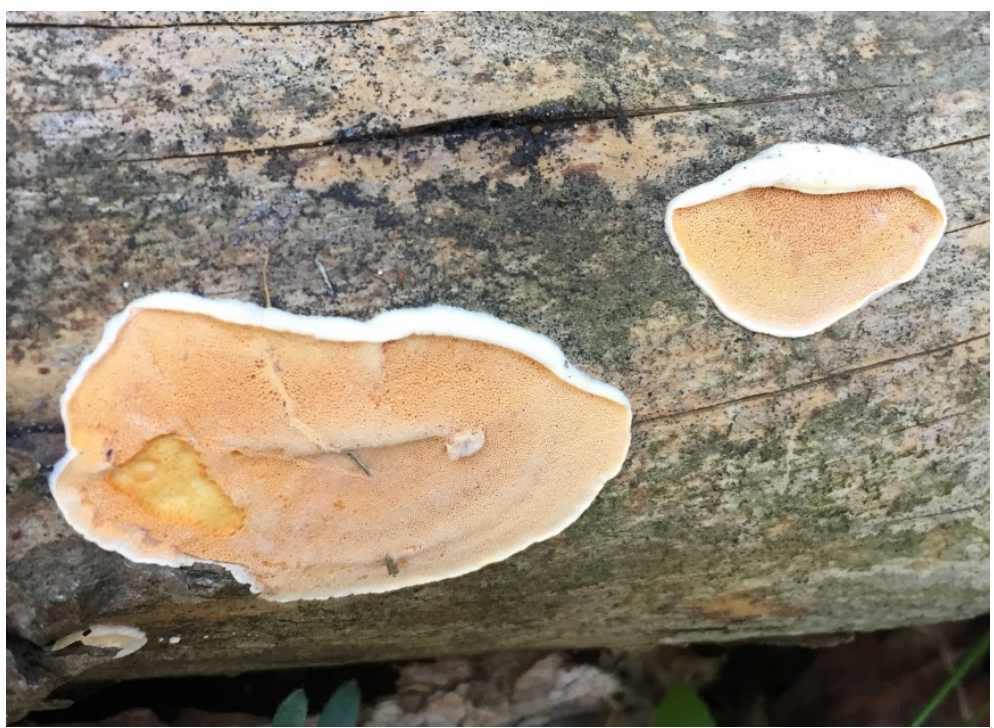

Figure 7. Basidiocarps of Skeletocutis amorpha (LE F-334638). Photo S.V. Volobuev

Рисунок 7. Базидиомы Skeletocutis amorpha (LE F-334638). Фото С.В. Волобуева 
Trametes hirsuta (Wulfen) Lloyd - \#9: on fallen trunk of Betula sp. in herb-rich birch forest with pine (LE F-334641).

Trametes ljubarskyi Pilát - \#9: on timber wood of Pinus kochiana (LE F-334639).

Trametes ochracea (Pers.) Gilb. \& Ryvarden - \#2: on dry fallen trunk of Betula sp. in herb-rich birch forest with pine (LE F-334642).

Trametes pubescens (Schumach.) Pilát - \#2, \#5: on dead standing tree and fallen trunk of Betula sp. in herb- rich birch forest and herb-rich birch forest with pine (LE F334643).

Trametes versicolor (L.) Lloyd - \#9, \#12: on fallen trunks of Betula sp. in herb-rich birch forest with pine and herb-fern birch forest (LE F-334644).

! Tyromyces kmetii (Bres.) Bondartsev \& Singer $\# 5$, \#8, \#23: on fallen trunks and branches of Betula spp. in herb-rich birch forest, herb-rich birch forest with pine and herb-green-moss pine-dominated forest (LE F-334647) (Fig. 8).

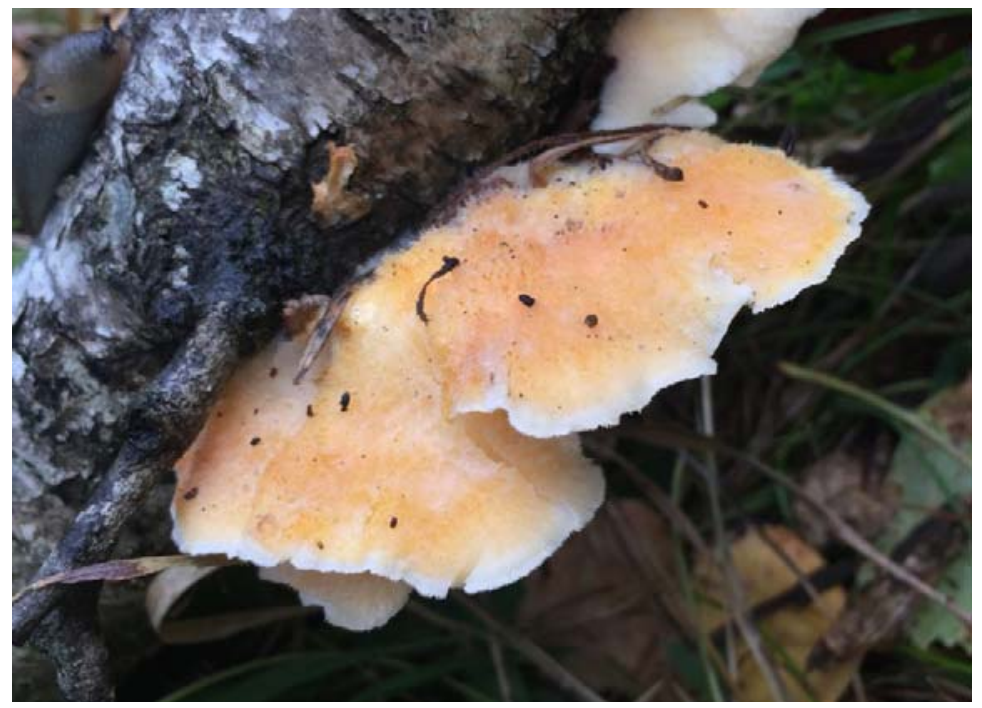

Figure 8. Basidiocarps of Tyromyces kmetii (LE F-334647). Photo S.V. Volobuev

Рисунок 8. Базидиомы Tyromyces kmetii (LE F-334647). Фото С.В. Волобуева

\section{RUSSULALES}

Heterobasidion annosum (Fr.) Bref. - \#15, \#25, \#26, \#29: on fallen trunks of Pinus kochiana and Betula sp., on stump of Pinus kochiana, on dead standing tree of Juniperus oblonga in herb-green-moss pine-dominated forest, herb-greenmoss pine-dominated forest with birch and herb-rich hornbeam forest with pine and birch (LE 314755, LE F334603) (Fig. 9).

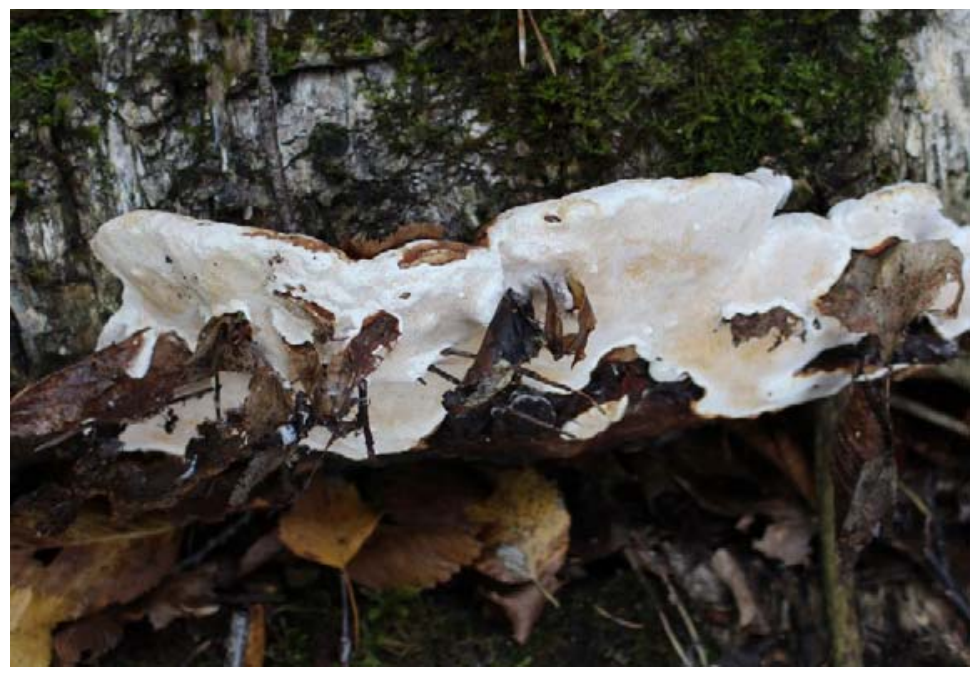

Figure 9. Basidiocarps of Heterobasidion annosum (LE F-334603). Photo Yu.Yu. Ivanushenko Рисунок 9. Базидиомы Heterobasidion annosum (LE F-334603). Фото Ю.Ю. Иванушенко

\section{TRECHISPORALES}

Porpomyces mucidus (Pers.) Jülich - \#21: on fallen branches of Betula sp. in herb-rich birch forest with hornbeam (LE F-334623).

! Trechispora candidissima (Schwein.) Bondartsev \& Singer - \#15: on fallen branches of Pinus kochiana in herbgreen-moss pine-dominated forest with birch (LE F334645).

\section{CONCLUSION}

The revealed species richness of polypores has expanded the current knowledge on the mycobiota of the Gunib Plateau and its links with plant communities. The vast majority of the species identified (65 species, 89\%) are xylosaprotrophs developing on dead wood of fallen trunks and branches. Poroid fungi, having a rich complex of lignocellulolytic enzymes, ensure the stability of the cycle 
of biogenic elements in forest ecosystems, and at the same time, are a sensitive indicator of anthropogenic changes in the nature environment. Further studies of poroid fungi in the Gunib Plateau should be aimed at assessing their indicator and conservation value.

\section{ACKNOWLEDGMENT}

This study was supported by the Russian Science Foundation (RSF project N 19-77-00085).

\section{БЛАГОДАРНОСТЬ}

Исследование выполнено при поддержке гранта РНФ №19-77-00085.

\section{REFERENCES}

1. Ghobad-Nejhad M., Bernicchia A. An outlook on the diversity of polypores shared between Iran and the Mediterranean area. Mycologia Iranica, 2019, vol. 6, iss. 1, pp. 33-39. DOI: 10.22043/mi.2020.121099

2. Bondartseva M.A., Parmasto E. Opredelitel' gribov SSSR. Poryadok afilloforovye; Vyp. 1. Semeistva gimenokhetovye, lakhnokladievye, konioforovye, shchelelistnikovye [Clavis diagnostica fungorum URSS. Ordo Aphyllophorales. Fasc. 1. Familiae Hymenochaetaceae, Lachnocladiaceae, Coniophoraceae, Schizophyllaceae]. Leningrad, Nauka Publ., 1986. 192 p. (In Russian)

3. Runnel K., Miettinen O., Lõhmus A. Polypore fungi as a flagship group to indicate changes in biodiversity - a test case from Estonia. IMA Fungus, 2021, vol. 12, iss. 2. https://doi.org/10.1186/s43008-020-00050-y 4. Nilsson R.H., Larsson K.H., Larsson E., Kõljalg U. Fruiting body-guided molecular identification of root-tip mantle mycelia provides strong indications of ectomycorrhizal associations in two species of Sistotrema (Basidiomycota). Mycological Research, 2006, vol. 110, iss. 12, pp. 1426-1432. DOI: 10.1016/j.mycres.2006.09.017

5. Di Marino E., Scattolin L., Bodensteiner P., Agerer R. Sistotrema is a genus with ectomycorrhizal species confirmation of what sequence studies already suggested. Mycological Progress, 2008, vol. 7, article number: 169, pp. 169-176. DOI: 10.1007/s11557-008-0562-4

6. Grienke U., Zöll M., Peintner U., Rollinger J.M. European medicinal polypores - A modern view on traditional uses. Journal of Ethnopharmacology, 2014, vol. 154, iss. 3, pp. 564583. DOI: 10.1016/j.jep.2014.04.030

7. Volobuev S.V., Ivanushenko Yu.Yu., Ismailov A.B. Auriporia aurulenta - kandidat v Krasnuyu knigu Respubliki Dagestan [Auriporia aurulenta - a proposal to the Red Data Book of the Republic of Dagestan]. Materialy Mezhdunarodnoy konferentsii "Flora i zapovednoe delo na Kavkaze: istoriya i sovremennoe sostoyanie izuchennosti", Pyatigorsk, 2019 [Proceedings of the International Conference "Flora and nature reserve management in the Caucasus: history and current state of knowledge", Pyatigorsk, 2019]. Pyatigorsk, 2019, pp. 32-33. (In Russian) 8. Ivanushenko Yu.Yu., Ismailov A.B., Volobuev S.V. Pervye svedeniya o trutovykh gribakh plato Gunib (Respublika Dagestan) [First data on polypores of the Gunib Plateau (the Republic of Dagestan)]. Materialy XXI Mezhdunarodnoi nauchnoi konferentsii "Biologicheskoe raznoobrazie Kavkaza i yuga Rossii". Magas, 15-18 noyabrya, 2019 [Materials of the XXI International Scientific Conference "Biological diversity of the Caucasus and Southern Russia", Magas, November 15-18, 2019]. Magas, 2019, pp. 163-166. (In Russian)

9. Ivanushenko Yu.Yu. [New finds of polypores on the Gunib plateau (Republic of Dagestan)]. Materialy
Mezhdunarodnogo molodezhnogo nauchnogo foruma "Lomonosov-2020», Moscow, MAKS Press, 2020. Available at: https://lomonosov-

msu.ru/archive/Lomonosov_2020/index.htm (accessed 25.12.2020)

10. Volobuev S.V., Ivanushenko Yu.Yu. Aphyllophoroid fungi (Basidiomycota) on juniper on the Gunib Plateau, innermountain Dagestan. Czech Mycology, 2020, vol. 72, iss. 1, pp. 83-93. DOI: $10.33585 / \mathrm{cmy} .72106$

11. Urbanavichus G., Ismailov A. The lichen flora of Gunib plateau, inner-mountain Dagestan (North-East Caucasus, Russia). Turkish Journal of Botany, 2013, no. 37, pp. 753-768. DOI: 10.3906/bot-1205-4

12. Omarova S.O. Flora lokal'nykh platoobraznykh podnyatii Vnutrigornogo Dagestana [Flora of local plateaus of Intramontane Dagestan]. Makhachkala, DSU Publ., 2013, 130 p. (In Russian)

13. Lodge D.J., Ammirati J.F., O’Dell T.E., Mueller G.M., Huhndorf S.M., Wang C.-J., Stokland J.N., Schmit J.P., Ryvarden L., Leacock P.R., Mata M., Umaña L., Wu Q.(F.), Czederpiltz D.L. Terrestrial and lignicolous macrofungi. In: Biodiversity of fungi. Inventory and monitoring methods. London; N.Y.; San Diego: Elsevier Academic Press, 2004, pp. 127-172.

14. Ivoilov A.V., Bolshakov S.Yu., Silaeva T.B. Izuchenie vidovogo raznoobraziya makromitsetov [Study of species diversity of macromycetes]. Saransk, University of Mordovia Publ., 2017, 160 p. (In Russian)

15. Ryvarden L., Melo I. Poroid fungi of Europe, 2nd edition. Synopsis Fungorum 37, 2017, pp. 1-431.

16. Bernicchia A., Gorjón S.P. Polypores of the Mediterranean Region. Romar, Segrate, 2020. 904 p.

17. Miettinen O., Vlasák J., Rivoire B., Spirin V. Postia caesia complex (Polyporales, Basidiomycota) in temperate Northern Hemisphere. Fungal Syst Evol., 2018, vol. 1, pp. 101-129. DOI: 10.3114/fuse.2018.01.05

18. White T.J., Bruns T., Lee S., Taylor J. Amplification and direct sequencing of fungal ribosomal RNA genes for phylogenetics. In: PCR protocols: a guide to methods and applications. San Diego, Academic Press, 1990, pp. 315-322. 19. Gardes M., Bruns T.D. ITS primers with enhanced specificity for Basidiomycetes: application to the identification of mycorrhizae and rusts. Mol Ecol., 1993, vol. 2, iss. 2, pp. 113-118. DOI: 10.1111/j.1365-

294x.1993.tb00005.x

20. Tamura K., Stecher G., Peterson D., Filipski A., Kumar S. MEGA6: Molecular Evolutionary Genetics Analysis version 6.0. Molecular Biology and Evolution, 2013, vol. 30, iss. 12, pp. 2725-2729. DOI: 10.1093/molbev/mst197

21. Basic Local Alignment Search Tool. Available at: https://blast.ncbi.nlm.nih.gov/Blast.cgi (accessed 10.01.2021)

22. GenBank. Available at: www.ncbi.nlm.nih.gov/genbank/ (accessed 20.01.2021)

23. Katoh K., Rozewicki J., Yamada K.D. MAFFT online service: multiple sequence alignment, interactive sequence choice and visualization. Briefings in Bioinformatics, 2019, vol. 20, pp. 1160-1166. DOI: 10.1093/bib/bbx108

24. MAFFT version 7. Available at:

http://mafft.cbrc.jp/alignment/server/ (accessed 20.01.2021)

25. Trifinopoulos J., Nguyen L.T., von Haeseler A., Minh B.Q. W-IQ-TREE: a fast online phylogenetic tool for maximum likelihood analysis. Nucleic Acids Research, 2016, vol. 44, iss. W1, pp. W232-W235. DOI: 10.1093/nar/gkw256 
26. Krasnaya kniga Respubliki Dagestan [Red Data Book of the Republic of Dagestan]. Makhachkala, Printing house of IE M.A. Jamaludinov, 2020, 800 p. (In Russian)

27. Index Fungorum. A nomenclature database. Available at: http://www.indexfungorum.org/Names/Names.asp. 2021. (accessed 08.01.2021)

28. Degteva S.V., ed. Krasnaya kniga Respubliki Komi [Red Book of the Komi Republic]. Syktyvkar, 2019. 768 p. (In Russian)

29. Gel'tman D.V., ed. Krasnaya kniga Leningradskoi oblasti: Ob"ekty rastitel'nogo mira [Red Data Book of the Leningrad Region: Objects of the Plant World]. SPb., Marafon Publ., 2018, 847 p. (In Russian)

30. Volobuev S.V. Aphyllophoroid fungi (Basidiomycota) of the "Verkhovskiy» State Nature Biological Sanctuary (Orel Region). Novosti sistematiki nizshikh rastenii, 2014, vol. 48, pp. 121-129. (In Russian) DOI: 10.31111/nsnr/2014.48.121 31. Volobuev S.V. Afilloforoidnye griby Orlovskoi oblasti: taksonomicheskii sostav, rasprostranenie, ekologiya [Aphyllophoroid fungi of the Oryol Oblast: taxonomical composition, distribution, ecology]. St. Petersburg, Lan' Publ., 2015, 304 p. (In Russian)

32. Zmitrovich I.V., Yurchenko E.O., Usichenko A.S., Malysheva V.F., Ordynets A.V. Afilloforovye i geterobazidial'nye griby [Aphyllophoroid and heterobasidioid fungi]. IX Rabochee soveshchanie Komissii po izucheniyu macromitsetov "Annotirovannye spiski vidov gribov i miksomitsetov", Rostov-on-Don, 4-10 oktyabrya 2006 [IX Workshop of the Commission on the study of macromycetes "Annotated lists of fungal and myxomycete species", Rostov-on-Don, 4-10 October, 2006]. Rostov-onDon, 2008, pp. 38-51. (In Russian)

33. Kotkova V.M. New data on aphyllophoraceous fungi of the Tsentralnolesnoy State Nature Biosphere Reserve (Tver' Region). Mikologiya i fitopatologiya. 2012, vol. 46, no. 6, pp. 361-364. (In Russian)

34. Shiryaev A.G., Kotiranta H., Mukhin V.A., Stavishenko I.V., Ushakova N.V. Aphyllophoroid fungi of Sverdlovsk region, Russia: biodiversity, distribution, ecology and the IUCN threat categories. Ekaterinburg, Goshchitskiy Publ., 2010, 304 p.

35. Zhukoff E.A. Aphyllophorales (Basidiomycetes) from Central Siberia. Mycotaxon. 1995, vol. 53, pp. 437-445. 36. Volobuev S.V., Bolshakov S.Yu., Shakhova N.V. Synopsis of the macrofungi (Basidiomycota) on wood of fruit trees in the Central Black Earth Region of Russia. South of Russia: ecology, development, 2020, vol. 15 , no. 4, pp. 75-98. DOI: 10.18470/1992-1098-2020-4-75-98

37. Bondartsev A.S. Trutovye griby Evropeiskoi chasti SSSR $i$ Kavkaza [The Polyporaceae of the European part of USSR and the Caucasus]. Moscow, Leningrad, 1953, 1106 p. (In Russian)

38. Hallenberg N. Synopsis of wood-inhabiting

Aphyllophorales (Basidiomycetes) and Heterobasidiomycetes from Northern Iran. Mycotaxon. 1981, vol. 12, iss. 2, pp. 473502.

39. Ghobad-Nejhad M., Hallenberg N., Parmasto E., Kotiranta H. A first annotated checklist of corticioid and polypore basidiomycetes of the Caucasus region. Mycologia Balcanica, 2009, vol. 6, iss. 3, pp. 123-168. DOI:

10.5281/zenodo. 2550071

\section{БИБЛИОГРАФИЧЕСКИЙ СПИСОК}

1. Ghobad-Nejhad M., Bernicchia A. An outlook on the diversity of polypores shared between Iran and the Mediterranean area // Mycologia Iranica. 2019. V. 6. Iss. 1. P. 33-39. DOI: 10.22043/mi.2020.121099
2. Бондарцева М.А., Пармасто Э.Х. Определитель грибов СССР. Порядок афиллофоровые; Вып. 1. Семейства гименохетовые, лахнокладиевые, кониофоровые, щелелистниковые / Отв. ред. М.В. Горленко. Л.: Наука, 1986. 192 с.

3. Runnel K., Miettinen O., Lõhmus A. Polypore fungi as a flagship group to indicate changes in biodiversity - a test case from Estonia // IMA Fungus. 2021. V. 12, Isss. 2. https://doi.org/10.1186/s43008-020-00050-y 4. Nilsson R.H., Larsson K.H., Larsson E., Kõljalg U. Fruiting body-guided molecular identification of root-tip mantle mycelia provides strong indications of ectomycorrhizal associations in two species of Sistotrema (Basidiomycota) // Mycological Research. 2006. V. 110. Iss. 12. P. 1426-1432. DOI: 10.1016/j.mycres.2006.09.017

5. Di Marino E., Scattolin L., Bodensteiner P., Agerer R. Sistotrema is a genus with ectomycorrhizal species confirmation of what sequence studies already suggested // Mycological Progress. 2008. V. 7. Article number: 169. P. 169-176. DOI: 10.1007/s11557-008-0562-4

6. Grienke U., Zöll M., Peintner U., Rollinger J.M. European medicinal polypores - A modern view on traditional uses // Journal of Ethnopharmacology. 2014. V. 154. Iss. 3. P. 564583. DOI: 10.1016/j.jep.2014.04.030

7. Волобуев С.В., Иванушенко Ю.Ю., Исмаилов А.Б. Auriporia aurulenta - кандидат в Красную книгу Республики Дагестан // Флора и заповедное дело на Кавказе: история и современное состояние изученности: материалы Международной конференции. Пятигорск, 2019. С. 32-33.

8. Иванушенко Ю.Ю., Исмаилов А.Б., Волобуев С.В. Первые сведения о трутовых грибах плато Гуниб (Республика Дагестан) // Материалы XXI Международной научной конференции “Биологическое разнообразие Кавказа и юга России". Магас, 15-18 ноября, 2019. С. 163166.

9. Иванушенко Ю.Ю. Новые находки трутовых грибов на плато Гуниб (Республика Дагестан) // Материалы Международного молодежного научного форума «Ломоносов-2020» / Отв.ред. И.А. Алешковский, А.В. Андриянов, Е.А. Антипов. М.: МАКС Пресс, 2020. URL: https://lomonosov-

msu.ru/archive/Lomonosov_2020/index.htm (дата обращения: 25.12.2020)

10. Volobuev S.V., Ivanushenko Yu.Yu. Aphyllophoroid fungi (Basidiomycota) on juniper on the Gunib Plateau, innermountain Dagestan // Czech Mycology. 2020. V. 72. Iss. 1. P. 83-93. DOI: $10.33585 / \mathrm{cmy} .72106$

11. Urbanavichus G., Ismailov A. The lichen flora of Gunib plateau, inner-mountain Dagestan (North-East Caucasus, Russia) // Turkish Journal of Botany. 2013. N 37. P. 753-768. DOI: 10.3906/bot-1205-4

12. Омарова С.О. Флора локальных платообразных поднятий Внутригорного Дагестана. Махачкала: Издательство ДагГУ, 2013, 130 с.

13. Lodge D.J., Ammirati J.F., O'Dell T.E., Mueller G.M., Huhndorf S.M., Wang C.-J., Stokland J.N., Schmit J.P., Ryvarden L., Leacock P.R., Mata M., Umaña L., Wu Q.(F.), Czederpiltz D.L. Terrestrial and lignicolous macrofungi. In: Biodiversity of fungi. Inventory and monitoring methods. London; N.Y.; San Diego: Elsevier Academic Press. 2004. P. 127-172.

14. Ивойлов А.В., Большаков С.Ю., Силаева Т.Б. Изучение видового разнообразия макромицетов: учебное пособие. Саранск: Изд-во Мордов. ун-та, 2017. 160 с.

15. Ryvarden L., Melo I. Poroid fungi of Europe, 2nd edition. Synopsis Fungorum 37. 2017. P. 1-431. 
16. Bernicchia A., Gorjón S.P. Polypores of the Mediterranean Region. Romar, Segrate, 2020. 17. Miettinen O., Vlasák J., Rivoire B., Spirin V. Postia caesia complex (Polyporales, Basidiomycota) in temperate Northern Hemisphere // Fungal Syst Evol. 2018. V. 1. P. 101129. DOI: $10.3114 /$ fuse.2018.01.05

18. White T.J., Bruns T., Lee S., Taylor J. Amplification and direct sequencing of fungal ribosomal RNA genes for phylogenetics // PCR protocols: a guide to methods and applications. San Diego, Academic Press. 1990. P. 315-322. 19. Gardes M., Bruns T.D. ITS primers with enhanced specificity for Basidiomycetes: application to the identification of mycorrhizae and rusts // Mol Ecol. 1993. V. 2. Iss. 2. P. 113-118. DOI: $10.1111 /$ j.1365294x.1993.tb00005.x

20. Tamura K., Stecher G., Peterson D., Filipski A., Kumar S. MEGA6: Molecular Evolutionary Genetics Analysis version $6.0 / /$ Molecular Biology and Evolution. 2013. V. 30. Iss. 12. P. 2725-2729. DOI: 10.1093/molbev/mst197

21. Basic Local Alignment Search Tool. URL: https://blast.ncbi.nlm.nih.gov/Blast.cgi (дата обращения: 10.01.2021)

22. GenBank. URL: www.ncbi.nlm.nih.gov/genbank/ (дата обращения: 20.01.2021)

23. Katoh K., Rozewicki J., Yamada K.D. MAFFT online service: multiple sequence alignment, interactive sequence choice and visualization // Briefings in Bioinformatics. 2019. V. 20. P. 1160-1166. DOI: 10.1093/bib/bbx108

24. MAFFT version 7. URL:

http://mafft.cbrc.jp/alignment/server/ (дата обращения: 20.01.2021)

25. Trifinopoulos J., Nguyen L.T., von Haeseler A., Minh B.Q. W-IQ-TREE: a fast online phylogenetic tool for maximum likelihood analysis // Nucleic Acids Research. 2016. V. 44. Iss. W1. P. W232-W235. DOI: 10.1093/nar/gkw256

26. Красная книга Республики Дагестан. Махачкала: Типография ИП Джамалудинов М.А., 2020. 800 c. 27. Index Fungorum. A nomenclature database. URL: http://www.indexfungorum.org/Names/Names.asp. 2021. (дата обращения: 08.01.2021)

28. Красная книга Республики Коми / гл. ред. С.В. Дёгтева. Сыктывкар: ООО «Коми республиканская типография», 2019. 768 с.

\section{AUTHOR CONTRIBUTIONS}

All authors collected the material, discussed the results and participated in the writing of the manuscript. Sergey V. Volobuev and Yuliya Yu. Ivanushenko carried out the microscopic identification of species and the molecular study of the collected specimens. All authors are equally responsible for plagiarism, self-plagiarism and other ethical transgressions.

\section{NO CONFLICT OF INTEREST DECLARATION}

The authors declare no conflict of interest.
29. Красная книга Ленинградской области: Объекты растительного мира / гл. ред. Д.В. Гельтман. СПб.: Марафон, 2018. 847 c.

30. Volobuev S.V. Aphyllophoroid fungi (Basidiomycota) of the "Verkhovskiy» State Nature Biological Sanctuary (Orel Region) // Novosti sistematiki nizshikh rastenii. 2014. V. 48. P. 121-129. (In Russian) DOI: 10.31111/nsnr/2014.48.121 31. Волобуев С.В. Афиллофороидные грибы Орловской области: таксономический состав, распространение, экология. СПб.: Лань, 2015. 304 с.

32. Змитрович И.В., Юрченко E.O., Usichenko A.S., Malysheva V.F., Ordynets A.V. Афиллофоровые и гетеробазидиальные грибы // IX Рабочее совещание Комиссии по изучению макромицетов «Аннотированные списки видов грибов и миксомицетов», Ростов-на-Дону, 4-10 октября 2006, С. 38-51.

33. Коткова В.М. Новые сведения об афиллофоровых грибах Центральнолесного государственного природного биосферного заповедника (Тверская область) // Микология и фитопатология. 2012. Т. 46. N 6. С. 361-364. 34. Shiryaev A.G., Kotiranta H., Mukhin V.A., Stavishenko I.V., Ushakova N.V. Aphyllophoroid fungi of Sverdlovsk region, Russia: biodiversity, distribution, ecology and the IUCN threat categories. Ekaterinburg, Goshchitskiy Publ., 2010, 304 p.

35. Zhukoff E.A. Aphyllophorales (Basidiomycetes) from Central Siberia // Mycotaxon. 1995. V. 53. P. 437-445. 36. Волобуев С.В., Большаков С.Ю., Шахова Н.В. Обзор макромицетов (Basidiomycota), развивающихся на древесине плодовых деревьев в условиях Центрального Черноземья России // Юг России: экология, развитие. 2020. T. 15. N 4. C. 75-98. DOI: 10.18470/1992-1098-2020-475-98

37. Бондарцев А.С. Трутовые грибы Европейской части СССР и Кавказа. Москва, Ленинград, 1953. 1106 с. 38. Hallenberg N. Synopsis of wood-inhabiting Aphyllophorales (Basidiomycetes) and Heterobasidiomycetes from Northern Iran // Mycotaxon. 1981. V. 12. Iss. 2. P. 473502.

39. Ghobad-Nejhad M., Hallenberg N., Parmasto E., Kotiranta H. A first annotated checklist of corticioid and polypore basidiomycetes of the Caucasus region. Mycologia Balcanica. 2009. V. 6. Iss. 3. P. 123-168. DOI:

10.5281/zenodo. 2550071

\section{КРИТЕРИИ АВТОРСТВА}

Все авторы участвовали в сборе материала, обсуждении результатов и написании рукописи. Сергей В. Волобуев и Юлия Ю. Иванушенко выполнили микроскопическую идентификацию видов и молекулярно-генетическое изучение собранных образцов. Все авторы в равной степени несут ответственность за плагиат, самоплагиат и другие неэтические проблемы.

\section{КОНФЛИКТ ИНТЕРЕСОВ}

Авторы заявляют об отсутствии конфликта интересов. 